\title{
Zarys historii Parafii Prawosławnej Zwiastowania NMP i św. Jana Teologa w Supraślu
}

\author{
hieromnich Pantelejmon Karczewski \\ Monaster Zwiastowania Przenajświętszej Bogarodzicy w Supraślu \\ Polska \\ ORCID: 0000-0003-0829-1781 \\ pawel-karczewski@gazeta.pl
}

\begin{abstract}
rev. P. Karczewski, The outline of the history of the Orthodox Parish of the Annunciations of the Mother of God and St. John Theologian in Supraśl, Elpis, 21 2019: 99-108.

Abstract: The Orthodox parish in Supraśl exists together with the Supraśl Monastery and is inseparably connected with it. Although the history of the monastery dates back to the 90 s of the 15 th century, the parish was created in 1800 . In 1839 , the monastic community returned to the Orthodox Church, after two hundred years of being under the "occupation" of the union. The outbreak of the First World War caused the evacuation of monks into the depths of Russia. In 1918, the Polish government took over church property. Parishioners were allowed to use only a small cemetery church - the care of the faithful was taken by by the Wasilków parish, from which in 1931 a branch parish of Supraśl was separated. During the Second World War, the Nazi army blown up the main monastery church. The post-war period is the time of struggles for regaining the church and buildings, as well as the constant development of parish life. In the early 1980s, Bishop of Białystok Sawa began to make efforts to revive the monastery. In 1984, Fr. Miron came to Supraśl and became the rector of the parish and the head of the monastery. Monastic life began to develop, and along with it, the spiritual life of parishioners deepened. In 1993, the state finally returned the monastery to the Orthodox Church. Currently, the Supraśl parish conducts its active activities outside the walls of the Monastery, which was evidenced e.g. by the consecration of the church in honor of St. Luke the Surgeon in the village Łaźnie in 2019.
\end{abstract}

Streszczenie: Parafia Prawosławna w Supraślu istnieje przy Supraskim Monasterze i jest z nim nierozłącznie związana. Choć historia Monasteru sięga lat 90-tych XV wieku, parafię utworzono w 1800 r. W 1839 roku wspólnota monasterska powróciła do Prawosławia, po dwustu latach przebywania pod „okupacją” unii. Wybuch I Wojny Światowej spowodował ewakuację mnichów w głąb Rosji. W 1918 r. polski rząd przejął mienie cerkiewne. Parafianom pozwolono na użytkowanie jedynie małej cmentarnej świątyni - opiekę nad wiernymi sprawowała wasilkowska parafia, z której w 1931 r. wydzielono filialną supraską parafię. Podczas II Wojny Światowej hitlerowskie wojska wysadziły w powietrze główną monasterską cerkiew. Okres powojenny to czas walk o odzyskanie cerkwi i budynków, a także ciągłe rozwijanie życia parafialnego. Na początku lat 80-tych nowy ordynariusz diecezji białostocko-gdańskiej biskup Sawa zaczął czynić starania o odrodzenie Monasteru. W 1984 r. do Supraśla trafił o. Miron, który został proboszczem parafii i przełożonym Monasteru. Zaczęło się rozwijać życie monastyczne, a wraz z nim pogłębiło się duchowe życie parafian. W $1993 \mathrm{r}$. państwo ostatecznie przekazało Monaster Kościołowi Prawosławnemu. Obecnie supraska parafia prowadzi swoją aktywną działalność także poza murami Monasteru, czego ważnym dowodem było poświęcenie cerkwi ku czci św. Łukasza Chirurga we wsi Łaźnie w $2019 \mathrm{r}$.

Keywords: Supraśl, monastery, Mularczyk, Makal, Miron Chodakowski

Słowa kluczowe: Supraśl, monaster, Mularczyk, Makal, Miron Chodakowski

Parafia Prawosławna w Supraślu jest parafią przymonasterską. Jej funkcjonowanie związane jest nierozłącznie $\mathrm{z}$ Monasterem, a zawiła historia $\mathrm{z}$ wieloma trudnymi i tragicznymi momentami jest nierozerwalnie związana $\mathrm{z}$ historią życia monastycznego na supraskiej ziemi.

\section{Pierwsze wieki Monasteru Supraskiego}

Początki Supraskiego Monasteru siegają 90-tych lat $\mathrm{XV}$ wieku. Wtedy to marszałek Wielkiego Księstwa Litewskiego Aleksander Chodkiewicz wraz z arcybiskupem smoleńskim Józefem Sołtanem założyli monaster w Gródku. Około 1500 r. wspólnota przeniosła się wzdłuż rzeki Supraśl na jej dzisiejsze miejsce. Jej ówczesnym przełożonym był ihumen Pafnucy.
W 1501 r. wzniesiono cerkiew św. Jana Teologa, a w latach 1503-1511 murowaną świątynię Zwiastowania Bogurodzicy. A. Mironowicz pisze: „Wobec panującego na terenie Wielkiego Księstwa Litewskiego oficjalnego zakazu budowy cerkwi murowanych, wymagana była zgoda królewska na wzniesienie takiej świątyni. Ihumen Pafnucy Sieheń wystąpił z taką prośbą do króla na początku 1509 r. W połowie marca $1509 \mathrm{r}$. Zygmunt Stary wyraził zgodę na wybudowanie murowanej cerkwi." (Mironowicz, 2013). W 1503 r. metropolita Józef Sołtan ofiarował monasterowi kopię Smoleńskiej Ikony Matki Bożej, która to stała się najbardziej czczona świętością nazywaną odtąd Supraską Ikoną Matki Bożej. W 1505 (1504?) roku patriarcha Konstantynopola Joachim $(1498-1502,1504)$ nadał tomos oficjalnie uznający Supraski Monaster (https://www.ec-patr. org/list/index.php?lang=gr). Niedługo później - w 1514 r. - Supraślowi nadano status patriarszej stauropigii (pod- 
legania bezpośrednio patriarsze). W 1589 r. do Supraśla przybył patriarcha konstantynopolitański Jeremiasz. W połowie XVI w. wzniesiono cerkiew Zmartwychwstania Pańskiego wraz z katakumbami przeznaczonymi do pochówku mnichów (Borowik, 2000, s. 28-29).

Monaster bardzo szybko stał się jednym z głównych ośrodków monastycznych i kulturowych i na ziemiach słowiańskich. Freski mnicha Nektariusza, które powstały w XVI w. za czasów archimandryty Sergiusza (Kimbara) w cerkwi Zwiastowania, a także zbiory w monasterskiej bibliotece i wielki dorobek muzyczno-piśmienniczy (Kodeks Supraski, Irmologion Supraski) świadczą o ścisłych związkach Monasteru z prawosławną Serbią, Mołdawią, Bułgarią i Grecją.

W 1596 r. w Brześciu odbył się synod, który odrzucił projekt unii. Aktywnie uczestniczył w nim supraski archimandryta Hilarion (Massalski), pozostając wiernym Prawosławiu. Jednak w 1614 r., już po jego śmierci, unia została narzucona supraskiemu monasterowi siłą, a wraz z nią w 1635 r. monastyczna reguła bazyliańska. Czasy, kiedy monaster nie znajdował się w rękach prawosławnych to okres stagnacji życia monastycznego. Powstała wtedy co prawda drukarnia i nowe budynki kompleksu monasterskiego, mimo to jednak sam monaster przybrał bardziej charakter biskupiej rezydencji, aniżeli kontynuatora starych wzorców monastycznych. Warto dodać, że w tym czasie znamienite fresku zostały zasłonięte rzeźbioną tabulatura.

\section{Od powrotu do Prawosławia do I Wojny Światowej (1839-1915)}

Monaster supraski powrócił do prawosławia w 1839 r. po soborze połockim. Przebywało w nim wówczas pięciu mnichów, znajdowała się tu także szkoła duchowna. Część zabudowań monasterskich zostało wydzierżawionych supraskiemu fabrykantowi Wilhelmowi Zachertowi (Surynowicz, 2001, s. 226). To czas wielu zmian, jak chociażby budowa nowej drogi do Białegostoku (dzisiejsza ul. Białostocka), która w 1836 r. przedzieliła supraski cmentarz na dwie części. Południową połowę przekazano prawosławnym. Wiadomo, że już w 1844 r. cmentarz był całkowicie zapełniony, toteż zezwolono na powiększenie jego terytorium.

Niedługo później - w 1849 r. - zamknięto istniejącą od 1800 r. (Makal, 2003, s. 21) parafię przymonasterską, a prawosławnych wiernych rozdzielono między Wasilków, Dojlidy, Ostrów i Sokółkę (Dalmatov, 1892, s. 419). Od tej pory na cmentarzu zaczęto chować także mnichów. W 1875 r. na grobie archimandryty Nikodema (Żelezowskiego) wzniesiona została drewniana cerkiew św. Pantelejmona. Po okresie unii świątynie monasterskie były $\mathrm{w}$ fatalnym stanie. Basztom cerkwi Zwiastowania groziło runięcie. Freski były uszkodzone, a ostatecznie zniszczono je, zabielając ściany w latach 50-tych. XIX w.

W 1881 r. supraskim przełożonym zostaje archimandryta Mikołaj (Dołmatow), który po stagnacji w okresie unii zdołał odrodzić życie monastyczne. Wyremontowano budynki, spisano historię monasteru. Przełożony dokonał także renowacji zamalowanych fresków w cerkwi Zwiastowania. Koniec XIX wieku to także czas budowy nowej cerkwi św. Jana Teologa, która swoim wezwaniem miała nawiązywać do pierwszej cerkwi w monasterze. Nową świątynię poświęcono 26 września 1890 r. W 1897 r. prawosławnym mieszkańcom Supraśla, Sokołdy i Łazień zezwolono na korzystanie w supraskiej cerkwi ze wszystkich obrzędów, z wyjątkiem ślubów (Bendza, 2005, s. 85).

W 1893 r. przy monasterze powstało Bractwo Zwiastowania NMP mające na celu krzewienie wiary i moralności oraz wzmacnianie ducha prawosławia okolicznej ludności. Stowarzyszenie zrzeszało sympatyków Monasteru - duchownych i świeckich. Jego honorowymi członkami zostali m.in. arcybiskup litewski i wileński Donat czy gubernator grodzieński (Shved, 2015, s. 287-288). Swoją działalnością bractwo obejmowało parafie dojlidzką i wasilkowską, ale głównym zadaniem było wspomaganie monasteru. Na początku działalności liczyło 68 członków, a już w 1900 r. 450 członków (Mironowicz, 2006, s. 503).

W 1900 r. cmentarz był znów zapełniony, a dalsze jego poszerzenie nie było możliwe. Istniała zatem potrzeba założenia nowego. Powstał on za rzeką na Podsupraślu (przy drodze w kierunku Krynek). Na nowo powstałym cmentarzu wzniesiono cerkiew. Odbyło się to z inicjatywy Bractwa Supraskiego, z pomoca miejscowych luteran i fabrykanta Adolfa Bucholza, z którym łączyły Monaster bardzo dobre relacje (Bendza, 2005, s. 85). Świątynia była potrzebna dla odprawiania pogrzebów. Została poświęcona ku czci św. wlk. męcz. Jerzego Zwycięzcy, patrona supraskiego bractwa, w dniu 11 listopada 1901 roku (Borowik, 2000, s. 28).

W 1910 r. supraskie bractwo rozpoczęło wydawanie periodyku „Supraskij Bratskij Listok”. Czasopismo prezentowało żywoty świętych i ludzi zasłużonych dla Prawosławia, podejmowało tematy religijne i społeczne. W tym samym czasie w Supraślu prowadzono kursy przygotowawcze dla psalmistów, dyrygentów i chórzystów. Suprascy hieromnisi wspomagali również kler pobliskich parafii, odprawiając nabożeństwa w razie potrzeby. O randze monasteru na początku XX wieku świadczy m.in. fakt, że biskup Włodzimierz (Tichonicki), powołany na wikariusza diecezji grodzieńsko-brzeskiej z tytułem biskupa białostockiego, został mianowany także przełożonym supraskiego monasteru (Bendza, 2005, s. 87). Stał się on tym samym następcą archimandryty Mikołaja zmarłego w $1906 \mathrm{r}$.

Niedługo później wybuchła I Wojna Światowa. Wydarzenie to spowodowało ewakuację mnichów. Supraśl i okolice opuściło wówczas wielu prawosławnych mieszkańców. Dynamiczny rozwój monasteru został przerwany w 1915 roku, kiedy większość ludności prawosławnej na polecenie władz carskich została ewakuowana w głąb Rosji. Większość mnichów opuściło Monaster 15 sierpnia 1915 roku. Zabrali ze sobą ważniejsze ikony, utensylia i dokumenty. Reszta mienia ruchomego zaginęła. 


\section{Czasy międzywojenne do utworzenia parafii filialnej (1918-1931)}

Po odzyskaniu niepodległości przez Polskę w listopadzie $1918 \mathrm{r}$. w ramach akcji rewindykacji cerkwi prawosławnych rząd przejął całe mienie cerkiewne jako należące wcześniej do rządu rosyjskiego, tzw. mienie pozaborcze. Prawosławie postrzegane było jako relikt zaborów. Wszystkie zabudowania przeszły pod tymczasowy zarząd skarbu państwa. Warto dodać, że w tym czasie Kościół prawosławny utracił znaczną część swego majątku, a sytuacja prawna nieruchomości, którymi dysponował, często było nieuregulowana (Kuprianowicz, 2009, s. 761). 8 sierpnia 1919 r. przybył do Supraśla inspektor Zbigniew Łaszczyński. W towarzystwie burmistrza miasta Władysława Kozłowskiego i sekretarz Marii Rothert zamknął i zapieczętował cerkiew Zwiastowania. Wcześniej hieromnich Sawa (Gawryluk), który jako jedyny z mnichów pozostał w monasterze, otrzymał polecenie, aby razem ze stróżem cerkiewnym Antonim Krauczukiem, przenieść wszystkie utensylia cerkiewne i przedmioty ruchome do cerkwi św. Jana Teologa, której również nie pozwolono użytkować (Archiwum Monasteru). Odebrany został także dawny cmentarz prawosławny z cerkwią św. Pantelejmona przy ul. Białostockiej. Przejęła go parafia rzymskokatolicka.

Nadzór nad świątynią Zwiastowania sprawował odtąd burmistrz, a od 1922 r. Okręgowa Dyrekcja Dróg Publicznych, która przejęła także zarządzanie nad cerkwią św. Jana, przyległym do niej budynkiem i dzwonnicą. Pieczę nad pozostałymi budynkami sprawował Wydział Powiatowy Sejmiku Białostockiego, który w 1922 r. przeznaczył budynki monasterskie na siedzibę Szkoły Rolniczej. Cele mnisze zamieszkiwali wówczas wspomnieni już ojciec Sawa i stróż Antoni. Zostali oni wezwani do opuszczenia murów. Po wielu protestach, ojciec Sawa - duchowny obsługujący parafię i zabezpieczający duchowe potrzeby wiernych - został w dniu 27 maja $1924 \mathrm{r}$ na polecenie wojewody usunięty $\mathrm{z}$ monasteru.

Parafianie starali się odzyskać swoje cerkwie i monasterskie budynki. Wystąpili m.in. do posła ziemi białostockiej Hellicha, a następnie do samego Naczelnika Państwa Józefa Piłsudskiego. Bractwo Supraskie w podaniu pisało:

My jako lud naszej Polski wszyscy jak jeden stoim $w$ szeregach naszych polskich wojsk, jak syny, tak bracia, a z konstytucji my po religii ściśnięte. Nie mamy nawet domu Bożego dla modlitwy. Na podanie nasze nie daje nam Rzad żadnej odpowiedzi. To my się zwracamy z pokorna prośba do Pana Naczelnika Polskiego Państwa i prosim sprawiedliwego sadu - odkryć nam światynie. Co się liczy monasterskich gmachów i ziemi, my z tego tylko prosim aby nam byto dane zabudowanie od dzwonnicy i Jana Bogostowa cerkiew, bo to jedne przy drugim. A reszte my nie dochodzim. Co się tyczy prawosławnego świaszczennika, to my zobowiazujemy się utrzymać na swoje koszta, bo bez modlitwy i pasterza cerkwi my odziczejem i słabe będziemy syny ojczyzny (Archiwum Monasteru).

Pismo pozostało bez odpowiedzi ze strony Naczelnika Państwa. Wyjaśnień zażądało jednak Ministerstwo Wyznań, na co wojewoda odpowiedział: „W Supraślu jest (sic!) cztery cerkwie prawosławne, a to: 1) wielka cerkiew, 2) mała cerkiew, tzw. ciepła zbudowana dla użytku byłego przeora na 600 osób, 3) mała cerkiewka na nowym cmentarzu, murowana z cegły, 4) kaplica drewniana na starym cmentarzu" (Archiwum Monasteru). Wojewoda stwierdził, że na potrzeby parafian wystarczy jedynie cmentarna cerkiew. Nie sprzeciwił się otwarciu jej i umożliwieniu sprawowania nabożeństw przez duchownego z Wasilkowa.

Wasilkowska parafia objęła duszpasterską opieką mieszkańców Supraśla i okolicznych wsi w 1924 r., o czym świadczy fakt nowych wpisów w księgach metrykalnych. W 1927 r. do parafii w Wasilkowie, której proboszczem był o. Włodzimierz Drużyłowski, trafił o. Aleksy Mularczyk z Grodna (ur. 29 lipca 1894 r. we wsi Zarudawie w powiecie wołkowyskim), wychowanek mnichów Pustyni Glińskiej w Rosji (Radziukiewicz, 2015, s. 134). Duchowny był przeznaczony do posługi w Supraślu.

Przez cały czas mieniem monasterskim zainteresowany był Kościół rzymskokatolicki. Na temat Supraśla obradowały komisje i zespoły złożone z przedstawicieli Kościoła i Rządu. 4 października 1927 r. do Supraśla przyjechał rzymskokatolicki arcybiskup Romuald Jabłrzykowski, ordynariusz diecezji wileńskiej. Odprawił on uroczystą mszę i dokonał „poświęcenia” cerkwi Zwiastowania. Przekazał następnie klucze świątyni supraskiemu proboszczowi ks. Ottonowi Sidorowiczowi. Odbyło się to wbrew decyzji starosty białostockiego M. Zborowskiego. Metropolita warszawski i całej Polski Dionizy (Waledyński), zaniepokojony sprawą, napisał do Ministerstwa Wyznań w $1928 \mathrm{r}$ :

Klasztor ten po wojnie został zamknięty i jakkolwiek nie zostat formalnie odebrany wyznaniu prawostawnemu, jednakże nie byt zwrócony duchowieństwu prawostawnemu. Odprawienie mszy przez ks. arcybiskupa Jałbrzykowskiego wywołało zrozumiate zaniepokojenie wśród okolicznej ludności prawosławnej, stusznie uważajacej klasztor supraski i jego światynie za prawostawne (...) Czy wtadze Państwowe upoważnity duchowieństwo rzymskokatolickie do objęcia klasztoru supraskiego, czy też abp Jałbrzykowski $w$ danym razie działal bez porozumienia $z$ władzami państwowymi?" (Archiwum Monasteru).

Suprascy parafianie napisali list do Arcybiskupa Grodzieńskiego Aleksego z prośbą o delegowanie ojca Mularczyka na stałe do Supraśla:

My, niżej podpisani parafianie Supraskiej Cerkwi zebraliśmy się $w$ liczbie 87 osób i uchwaliliśmy prosić o delegowanie do nas duchownego Aleksego Mularczyka. Jednocześnie obowiazujemy się dać naszemu duchownemu własne utrzymanie na koszt parafialny po 150 złotych miesięcznie, jak również obowiazujemy się wynajmować dla wymienionego duchownego potrzebny lokal na mieszkanie kosztem naszej parafii (Archiwum Monasteru). 
Tymczasem monasterem zaczęli interesować się także unici. Grekokatoliccy duchowni wykazali ożywioną działalność w niektórych rejonach Białostocczyzny, o czym pisał metropolita Dionizy we wspomnianym wcześniej liście do Ministerstwa Wyznań:

Jednemu z księży prawosławnych ofiarowano objęcie parafii unickiej $w$ Supraślu proponujac mu $w$ uposażeniu: grunt, ogród monasterski $i$ dotacje pieniężna. Na prośby Supraślan ks. biskup Grodzieński wyznaczyt księdza prawostawnego celem petnienia postug religijnych w Supraślu. W odpowiedzi Urzad Wojewódzki zabronit mu pobytu w Supraślu. Tak więc do Supraśla, gdzie nie ma ani jednego unity, może być mianowany ksiąd unicki, natomiast nie może tam zamieszkać ksiądz prawosławny dla obstugi licznej ludności prawosławnej (Archiwum Monasteru).

Wojewoda białostocki, stosunkując się do listu stwierdził, że agitacji ze strony duchowieństwa unickiego, na terenie powiatu białostockiego, nie stwierdzono (Archiwum Monasteru). Po czterech miesiącach zmienił zdanie - „W powiecie białostockim prowadzona jest obecnie wśród ludności prawosławnej silna agitacja na rzecz wschodniosłowiańskiego, w wyniku czego utworzona została parafia tego obrządku w Fastach. Podobna agitacja prowadzona jest również i w Supraślu i możliwem jest utworzenie tam parafii wschodniosłowiańskiego obrządku, co uszczupli ilość prawosławnych miasta Supraśla i okolicy" (Archiwum Monasteru). Wojewoda uznał także za niewskazane osiedlenie się prawosławnego duchownego w Supraślu.

\section{Pierwsze lata parafii filialnej (1931-1939)}

10 marca 1931 r. decyzją arcybiskupa Aleksego o. Mularczyk oficjalnie objął nieetatową filię w Supraślu z poleceniem odprawiania nabożeństw w cmentarnej cerkwi św. Jerzego. Miesiąc później arcybiskup otrzymał w tej sprawie również pozytywną opinię wojewody Mariana Z. Kościałkowskiego. Rok 1931 to pierwszy rok, w którym zapisy metrykalne pojawiają się już w supraskich księgach. We wspomnianym roku odbyło się 36 chrztów, 7 ślubów i 10 pogrzebów (Kościół Prawosławny w Polsce dawniej i dziś. Aneks statystyczny z parafialnych ksiag metrykalnych biatostocczyzny XVIII, XIX i XX wieku, 1993, s. 107-108). Na podstawie listu parafian do Ministerstwa Wyznań Religijnych z 1937 r. można stwierdzić, że filia liczyła 1630 parafian i swoim zasięgiem obejmowała poza Supraślem także następujące wsie i kolonie: Ciliczanka (pisownia oryginalna, obecnie: Cieliczanka), Ogrodniczki, Ciasne, Karakule, Nowodworcy (pisownia oryginalna, obecnie: Nowodworce), Sadowy Stok, Jałówka, Ożynnik, Surażkowo, Sokołda, Łaźnie, Podłaźnie, Krzemienne, Konne, Międzyrzecze i Woronicze (Archiwum Monasteru).

W pierwszych latach funkcjonowania nowej filii jej utrzymanie spoczywało na barkach parafian. Zdołali oni jednak zakupić dwa dzwony i niezbędne utensylia oraz nabyć dom mieszkalny. Prowadzono próby chóru i lekcje religii. W latach 1934-1939 psalmistą w parafii był Jan Mieszków. Chór prowadził aż do 1945 r. Aleksander Backiel.

Pierwsze lata istnienia supraskiej filii to także czas sporów z Salezjanami (katolicka wspólnota zakonna, której głównym zadaniem jest praca z młodzieżą), którzy od 1925 r. dzierżawili budynki monasterskie. Prowadzili dom dziecka dla chłopców (Radziukiewicz, 2015, s. 134). Ich umowa miała trwać do 1948 r. Salezjanie nie byli nigdy wcześniej związani z Supraślem, a ich jedyny związek z monasterem polegał właśnie na umowie o dzierżawę. W 1937 r. zdjęli oni krzyże z cerkwi św. Jana Teologa. Spotkało się to ze sprzeciwem parafian. Starostwo Powiatowe w Białymstoku bezskutecznie zaproponowało prawosławnym ekwiwalent pieniężny za odstąpienie od roszczeń od tejże świątyni. Salezjanie oświadczyli, że również oni nie oddadzą cerkwi. Wynieśli z niej Golgotę, ikony z kiotami i inne przedmioty kultu. Umieścili je bez czci w Domu Ludowym w Supraślu. Po profanacji parafianie wystąpili na drogę sądową. Proces prowadzony w Sądzie Okręgowym w Białymstoku został rozstrzygnięty w 1938 r. na niekorzyść prawosławnych. Odwoływanie się od wyroku przerwał wybuch II Wojny Światowej w 1939 r.

\section{Czasy wojny w Supraślu (1939-1944)}

Na samym początku II Wojny Światowej w Supraślu stacjonowali Niemcy. Pod koniec września 1939 r. do miasta wkroczyły jednak wojska radzieckie. Sowieci zajęli dwie cerkwie, w których zorganizowali kuźnię i jadalnię. Zdjęli krzyże, zniszczyli ikonostas i sprofanowali grób archimandryty Mikołaja Dołmatowa. W prezbiterium cerkwi Zwiastowania urządzono kuchnię z dymiącymi kotłami.

Ojciec Mularczyk, mimo wielu trudności, nie opuścił parafii i przez cały czas sprawował nabożeństwa. Walentyna Hammer wspomina: „Był skromny, mimo iż posiadał dar tak bardzo cenny dla duchownego - prowadzenia wzruszających modłów. Był bardzo uduchowiony. Nabożeństwa celebrowane przez niego porywały wiernych. Na to w dużym stopniu wpływały jego uzdolnienia muzyczne. Miał wspaniały głos" (Archiwum Monasteru).

22 czerwca 1941 r. Supraśl ponownie zajęli Niemcy. Budynki monasterskie pozostawione przez Sowietów były w ruinie. Pod okupacją niemiecką udało się jednak odzyskać klucze od cerkwi św. Jana Teologa, którą w 1942 r. ponownie wyświęcono. Do monasteru powróciło także kilku mnichów na czele $\mathrm{z}$ archimandrytą Izydorem. Pomagali oni w posłudze o. Mularczykowi. W lipcu 1944 r. Niemcy zaczęli wycofywać się z Supraśla. Wygonili mnichów z monasteru. Pozostał jedynie ojciec Izydor, który stał się naocznym świadkiem olbrzymiej tragedii - wysadzenia w powietrze przez Niemców cerkwi Zwiastowania. Pozostałe budynki, poza tym, w którym przebywał mnich, zostały również zniszczone. Miasto Supraśl wyzwolono 26 lipca 1944 r. 


\section{Wojna po wojnie (1944-1958)}

Okres powojenny to czas walk o cerkiew św. Jana Teologa i kolejna odsłona sporu z Salezjanami. Odzyskaną w 1941 r. świątynię parafianie szybko odremontowali. Już we wrześniu 1944 r. Rada Miejska w Supraślu podjęła decyzję, by przekazać klasztor wraz z budynkami i ogrodem Zakładowi księży Salezjanów i „uznać go prawowitym właścicielem" (Archiwum Monasteru). Była to oczywiście decyzja zaskakująca, zważywszy na fakt, że jedyny związek Salezjanów z Supraskim Monasterem polegał na dzierżawieniu przez nich części budynków. Rada Parafialna w liście do starosty białostockiego napisała - „Co się tyczy budynków poklasztornych oraz cerkwi św. Jana Teologa - o oswobodzeniu takowych nie może być mowy. My swoją siłą i krwią obronimy drogą nam oraz naszym dzieciom świątynię" (Archiwum Monasteru). Proboszcz o. Mularczyk w oddzielnym piśmie stwierdził: „Gdy Wysoki Rząd Państwa naszego wymaga ode mnie oswobodzenia posesji poklasztornej wraz z Cerkwią św. Jana Teologa co stwarza dla mych wiernych wielką krzywdę, bo innej świątyni nie mają, uczynić tego nie mogę, gdyby nawet mnie za to groziła śmierć" (Archiwum Monasteru).

Los cerkwi św. Jana Teologa podzieliła wkrótce stara cmentarna cerkiew św. wlk. męcz. Pantelejmona (dawna cerkiew znajduje się na cmentarzu przy ul. Białostockiej po prawej stronie, jadąc z Białegostoku). Ojciec Mularczyk pisał: „Na starym monasterskim cmentarzu znajduje się drewniana, z kamienną dzwonnicą cerkiewka, zbudowana i poświęcona w 1878 roku, 30 kwietnia. Wymieniona cerkiew nigdy nie należała do unitów, ani tym bardziej katolików. Znajduje się ona w prawosławnej części cmentarza. Na tym cmentarzu odprawiałem panichidę i święciłem mogiły" (Archiwum Monasteru). W dniu rzymskokatolickiego święta Wszystkich Świętych 1 listopada 1944 r. zdjęto z niej prawosławny krzyż, a ksiądz odprawił w niej katolickie nabożeństwo.

Zabranie świątyń to nie jedyne środki terroru, jakich używano na prawosławnych mieszkańcach Supraśla. Wychowankowie prowadzonego przez Salezjanów zakładu opiekuńczo-wychowawczego starali się zastraszyć prawosławnych obrażając ich, obrzucając kamieniami czy wybijając okna w cerkwi i domu mieszkalnym, o czym pisze w korespondencji o. Mularczyk (Archiwum Monasteru). W maju 1945 r. zamordowanych zostało troje młodych ludzi, posądzonych o sympatie komunistyczne. Dwa tygodnie później zabito także rodziców jednego z nich. Bandyci planowali także zamordować synów o. Mularczyka, lecz ci zostali ostrzeżeni i zdołali uciec (Makal, 2003, s. 52-53).

Wkrótce napadnięci zostali mnisi zamieszkujący dom przy cerkwi św. Jana Teologa. Sprawcy wypędzili ich z budynku, który szybko przejęli księża Salezjanie. Starosta białostocki poinformował $\mathrm{w}$ swoim piśmie $\mathrm{z}$ końca lipca 1945 r. o planowanym „urzędowym wprowadzeniu księży Salezjanów w posiadanie całej posesji" (Archiwum Monasteru). Miało to się odbyć 9 sierpnia - w dniu św. Pantelejmona, patrona odebranej cmentarnej świątyni.
Rada Parafialna postanowiła interweniować w stolicy. W liście adresowanym do premiera Rządu Tymczasowego czytamy: „Każdy z nas żywi gorącą miłość i przywiązanie do cerkwi św. Jana Teologa, pobudowanej wyłącznie ofiarnością naszą i naszych ojców z dziada pradziada wyznających religię prawosławną (...) Salezjanie nigdy nie byli właścicielami klasztoru supraślskiego lecz tylko fikcyjnymi dzierżawcami jego" (Archiwum Monasteru). W 1948 r. umowa dzierżawna Salezjanów wygasła i nie została przedłużona. Opuścili oni miasto.

Od 1 września 1944 r. o. Mularczyk prowadził w szkole lekcje religii - w łączonych wielowiekowych grupach. W 1953 r. parafii przekazano dom nabyty w 1935 r. na nazwisko jednej z parafianek (obecny dom przy ul. 3. Maja 13).

Wkrótce właścicielem monasterskich zabudowań został Ośrodek Szkolenia Kadr Mechanizacji Rolnictwa. Rozpoczął się kolejny trudny czas dla supraskiej parafii. Odebrano cerkiew św. Jana Teologa, a arcybiskup Tymoteusz (Szretter), obawiając się możliwej profanacji, nakazał o. Mularczykowi zabranie z cerkwi przedmiotów kultu religijnego. Nabożeństwa były odtąd sprawowane ponownie w cmentarnej cerkwi św. Jerzego. Ojciec Aleksy utworzył również kaplicę w domu parafialnym. W lipcu $1957 \mathrm{r}$. przystąpiono do rozbiórki cerkwi św. Jana. Proboszcz wraz z radą parafialną próbowali interweniować zarówno na szczeblu wojewódzkim, jak i krajowym. Powołano specjalną komisję składającą się z przedstawicieli Urzędu do Spraw Wyznań, Ministerstwa Rolnictwa, Referatu Wyznań i Wojewódzkiego Urzędu Rolnictwa w Białymstoku. Zaproponowano przejęcie przez prawosławnych kościoła ewangelickiego. Parafianie zdecydowanie odmówili.

Pod koniec 1957 r. cerkiew św. Jana Teologa ostatecznie zwrócono prawosławnym. Była ona w bardzo złym stanie - pozbawiona dachu, ze zniszczonym wnętrzem. Przystąpiono do kapitalnego remontu. 9 października 1958 r. w dniu święta apostoła Jana cerkiew została ponownie poświęcona. Dopiero od tego czasu funkcję świątyni parafialnej przestała pełnić nieduża cmentarna cerkiew św. Jerzego.

W omawianym czasie psalmistą i dyrygentem chóru był do 1954 r. Julian Rakowski, a od 1954 r. do śmierci w 1956 r. Mikołaj Hajduk (Makal, 2003, s. 58).

\section{Przed odrodzeniem Supraskiego Monasteru (1958-1984)}

Wraz z odzyskaniem cerkwi św. Jana Teologa dla supraskiej parafii nastały względnie spokojne czasy wolne od prześladowań. Proboszcz zajmował się kończeniem remontu cerkwi św. Jana, odnawianiem wnętrza cerkwi św. Jerzego i poprawianiem ogrodzenia cmentarza. W $1968 \mathrm{r}$. zmarł syn ojca Aleksego - Borys. Został pochowany na wolskim cmentarzu w Warszawie. Niedługo później odszedł do Pana sam o. Mularczyk. Nastąpiło to 14 grudnia 
1970 r. Został pochowany na cmentarzu, przy cerkwi św. Jerzego.

Po śmierci o. Aleksego nabożeństwa odprawiane były przez kilka miesięcy przez różnych duchownych delegowanych przez białostockiego dziekana. W dniu 1 maja 1971 r. proboszczem supraskiej parafii został o. Aleksander Makal, 44-letni duchowni, który dotychczas przez czternaście lat był proboszczem w Wojnowie.

Ojciec Aleksander przystąpił do kolejnych remontów - na plebanii i w cerkwi św. Jana Teologa. Zajęcia z religii prowadzone były w trzech punktach - Supraślu, Ogrodniczkach i Łaźniach. Organizowano zabawy choinkowe dla dzieci. Od czasu utworzenia Domu Opieki w Łaźniach raz w miesiącu sprawowana tam była Święta Liturgia. Funkcję psalmisty pełniła matuszka Irena Makal wspomagana przez Wierę Karczewską z Ogrodniczek. W 1981 r. funkcję starosty cerkiewnego po Janie Antonowiczu z Podsokołdy przejął Józef Piech z Supraśla. W 1982 r. wikariuszem supraskiej parafii został na kilka miesięcy ks. Mirosław Tomaszewski.

W dniu święta Supraskiej Ikony Bogurodzicy (10 sierpnia) w 1975 r. abp Nikanor poświęcił odnowiony ołtarz w cerkwi św. Jana Teologa.

W 1981 r. nowym ordynariuszem diecezji białostocko-gdańskiej został biskup Sawa (Hrycuniak), który od razu zaczął czynić starania o odzyskanie ruin cerkwi Zwiastowania i odrodzenie życia monastycznego w Supraślu. Metropolita wspomina: „Do Białegostoku przybyłem 1 sierpnia 1981 roku, a już 6 listopada tegoż roku wystosowałem do odnośnych władz dokument w sprawie przekazania zarośniętych chwastami ruin świątyni Kościołowi prawosławnemu" (Hrycuniak, 2015, s. 13). Już w 1983 r. wojewoda białostocki wyraził zgodę na odbudowę zniszczonej świątyni. Po pozwoleniu Wojewódzkiego Konserwatora Zabytków latem 1983 r. przystąpiono do rozbiórki ceglanych ruin. Pomogła młodzież z Podlasia i całej Polski, która uczestniczyła w czterech obozach roboczych.

Po wymianie wielu pism urzędowych Naczelnik Miasta i Gminy w Supraślu wydał w listopadzie decyzję o przekazaniu działki, na której znajdowała się cerkiew Zwiastowania, w wieczyste użytkowanie parafii. Sobór Biskupów PAKP w swojej odezwie napisał: „Apelujemy niniejszym do wszystkich duchownych o rozpropagowanie wśród wiernych i wszystkich ludzi doceniających wagę tego przedsięwzięcia, oddanych Kościołowi i życzliwych mu - idei odbudowy tej świątyni. Uczyńmy ją naszą ogólnokościelną sprawą - zjednoczmy się wokół tej odbudowy" (Archiwum Monasteru).

3 czerwca 1984 r. wmurowano akt erekcyjny pod odbudowę cerkwi. W uroczystości wzięło udział 10 tys. pielgrzymów, w tym przybyły z Rumunii metropolita Oltenii Nestor. Biskup białostocki i gdański Sawa podczas nabożeństw powiedział: „O ile bowiem każda świątynia oddziałuje na społeczeństwo, jest potrzebna i wznosimy ją $\mathrm{z}$ radością, o tyle $\mathrm{w}$ tej kryje się historia i dusza prawosławia. Pragniemy, aby odrodziła się ona ku pokrzepieniu serc jako pomnik dla przyszłości i jako świadectwo prze- szłości" (Archiwum Monasteru). Na pamiątkę tego wydarzenia jednym $\mathrm{z}$ supraskich świąt parafialnych $\mathrm{w}$ swoim dekrecie $\mathrm{z}$ tego samego roku biskup Sawa ustanowił pierwszą niedzielę czerwca - jako rocznicę położenia kamienia węgielnego pod cerkiew Zwiastowania.

\section{Parafia i odradzanie się życia monastycznego (1984-1998)}

W czerwcu 1984 r. na wikariusza supraskiej parafii mianowany został hieromnich Miron (Chodakowski), który wcześniej przez pięć lat był przełożonym Monasteru św. Onufrego w Jabłecznej.

Po kilku miesiącach, 16 listopada 1984 r., biskup Sawa erygował Parafię Zakonną Zwiastowania NMP i św. Jana Teologa, a także Dom Zakonny. Proboszczem parafii i przełożonym Domu Zakonnego został ihumen Miron (Chodakowski). Dekret został przeczytany uroczyście przez biskupa Sawę po Liturgii w dniu 25 listopada.

Ks. Aleksandra Makala przeniesiono na parafię w Wasilkowie. Wspominał on: „Ludzie byli bardzo zadowoleni z informacji, że powstaje dom zakonny w Supraślu. Oczywiście nie zabrakło protestów naszych braci zachodnich. Znałem wcześniej ks. Mirona ze święta parafialnego w monasterze w Jabłecznej. Serdeczny człowiek. Bardzo pracowity. Gdy się spotkaliśmy w Supraślu pamiętam jak wspominał o tym, że pochłonie swój cały czas aby odbudowywać życie monastyczne i świątynię Zwiastowania NMP" (Archiwum Monasteru).

Wikariuszem parafii mianowano ojca Igora Chlobicza (został odwołany w kolejnym roku), psalmistą zaś Jarosława Makala (Archiwum Monasteru). W 1985 r. wikariuszem został ks. Anatol Kiryk.

Latem 1987 r. przystąpiono do remontu cerkwi św. Jana Teologa. Nabożeństwa przeniesiono do kaplicy cmentarnej i kaplicy domowej na plebanii, którą to po remoncie poświęcił biskup Sawa w 1985 r. Pierwsze nabożeństwo w cerkwi św. Jana po remoncie odbyło się wiosną $1988 \mathrm{r}$.

20 listopada 1987 r. do Supraśla przybył patriarcha Konstantynopola Dimitrios. To pierwsza wizyta patriarchy ekumenicznego w Monasterze po niemal 400 latach, kiedy to w 1589 r. Supraśl odwiedził patriarcha Jeremiasz II. Pierwsze lata funkcjonowania domu zakonnego to czas, kiedy Supraśl odwiedziło także wielu innych hierarchów. Kronika parafialna wymienia gości - metropolitę mińskiego i białoruskiego Filareta, metropolitę lwowskiego Nikodema, metropolitę smoleńskiego Cyryla (obecny Patriarcha Moskiewski i całej Rusi), biskupa Tichona z USA i biskupa Jana z Czechosłowacji (Archiwum Monasteru). Odrodzenie życia monastycznego w Supraślu stało się też impulsem do pogłębienia duchowego życia parafian. Wpływ na to miały m.in. środowe akatysty przed Supraską Ikoną Bogurodzicy, które gromadziły mnóstwo pielgrzymów. Ojciec Miron starał się odradzać kult ikony, m.in. rozpoczynając tradycję organizowania $\mathrm{z}$ pomocą bractwa młodzieży pieszych pielgrzymek na sierpniowe uroczystości. Ponadto dla parafian organizowano pielgrzymki. Wie- 
le osób przyjeżdżało także do zajmującego się ziołolecznictwem ojca Gabriela. Szczególną opieką duszpasterską otoczono również wsie znajdujące się na terenie parafii. W grudniu 1987 r. w Karakulach postawiono krzyż wiejski, przed którym rozpoczęto odprawiać nabożeństwa.

14 grudnia 1989 r. Sobór Biskupów PAKP podjął decyzję o restytucji Monasteru. Przełożonym został mianowany ihumen Miron, podniesiony w kolejnym roku do godności archimandryty.

W 1989 r. rozpoczęły się również starania o uznanie prawa własności do cerkwi św. Jana Teologa i budynków monasterskich. W $1990 \mathrm{r}$. sąd w swoim postanowieniu oddalił wniosek prawosławnych. Mnisi zaczęli się również starać o odzyskanie katakumb, będących pozostałością po dawnej cerkwi Zmartwychwstania.

Liczne trudności w kontaktach z Kościołem rzymskokatolickim sprawiły, że duchowni oraz wierni napisali list otwarty do Papieża Jana Pawła II. Pisali w nim:

Nasz niepokój budza dażenia Kurii Metropolitalnej w Biatymstoku do zawładnięcia kompleksu budynków Ławry Supraskiej, stanowiacej od wieków duchowo-kulturowe centrum mieszkańców tego regionu. Obecnie zaś na Białostocczyźnie nie ma katolików obrzadku bizantyjsko -ukraińskiego (...) Wierzymy, że stowa Waszej Światobliwości kierowane do prawostawnych wyrażaja szczere dażenia do pojednania wszystkich chrześcijan, o co Kościót Prawostawny modli się każdego dnia. Czy jednak możliwe jest budowanie jedności, prawdziwych braterskich stosunków, gdy nasze wysilki ratowania duchowego oraz kulturowego dziedzictwa sa torpedowane przez braci katolików? (Archiwum Monasteru).

To pismo oraz wizyta papieża w Białymstoku w 1991 r. wpłynęły na zmianę nastawienia Kościoła katolickiego i ocieplenie napiętych relacji.

W marcu $1991 \mathrm{r}$. prawosławni odzyskali po wielu latach starań budynek przyległy do cerkwi św. Jana, a następnie samą cerkiew. Budynki trzeba było wyremontować. Nie do przecenienia jest tu trud parafian i ludzi dobrej woli, którzy materiały budowlane przywozili nawet z odległych zakątków Polski.

W czerwcu 1992 r. z wizytą do Polski przybył Prezydent Białorusi Stanisław Szuszkiewicz. Odwiedził on również Supraśl, gdzie archimandryta Miron przypomniał mu o obietnicy złożonej przez białoruskich deputowanych o przekazaniu Monasterowi dzwonów. Prezydent Szuszkiewicz oświadczył także, że „podczas rozmów międzypaństwowych Lech Wałęsa zadeklarował swój patronat nad przekazaniem zespołu poklasztornego w Supraślu Polskiego Autokefalicznemu Kościołowi Prawosławnego (...) Oświadczenie to stało się sensacją pierwszych stron miejscowych gazet, które ogłosiły, że Supraśl staje się centrum prawosławia" (Nowa Europa, 20.07.1992).

Po wielu latach sporów i wymiany korespondencji 28 września 1993 r. szef Urzędu Rady Ministrów Jan Maria Rokita podjął decyzję o przekazaniu Supraskiego Monasteru Kościołowi Prawosławnemu. Do decyzji nie dodał jednak uzasadnienia, co zostało później wykorzystane na niekorzyść Cerkwi. W monasterskich budynkach swoją siedzibę miała wówczas Szkoła Mechanizacji Rolnictwa. Planowano przeprowadzenie szkoły do nowego budynku, który miał być zbudowany z budżetu Ministerstwa Rolnictwa. Decyzja ministra Rokity nie spodobała się Kościołowi rzymskokatolickiemu, toteż skargę wniosła Kuria metropolitalna. Naczelny Sąd Administracyjny w Warszawie w 1995 r. stwierdził nieważność decyzji Rokity. Po wielu działaniach Monaster został oficjalnie przekazany prawosławnym 28 lutego 1996 roku.

W 1995 r. do Supraśla przybyły nowe dzwony. Powieszono je na monasterskiej dzwonnicy. Niedługo później dyrekcja szkoły nakazała zdjęcie dzwonów, czego archimandryta Miron nie uczynił. W związku z tym na prawie rok zamknięto dostęp do dzwonnicy (Archiwum Monasteru). Przez cały czas trwały prace nad odbudową cerkwi Zwiastowania. Kierownikiem budowy był Bazyli Krysiuk, który, podsumowując trud po wielu latach, powiedział: „To najważniejsza budowa w moim życiu" (Radziukiewicz, 2015, s. 142).

\section{Czasy najnowsze (od 1998)}

Rok 1998 przyniósł duże zmiany zarówno dla Monasteru jak i parafii. W lutym zmarł zwierzchnik PAKP metropolita warszawski i całej Polski Bazyli. Trzech supraskich mnichów zostało wybranych na biskupów - archimandryta Miron na biskupa hajnowskiego, wikariusza diecezji warszawsko-bielskiego, Prawosławnego Ordynariusza Wojskowego; ihumen Jakub na biskupa supraskiego, wikariusza diecezji białostocko-gdańskiej; ihumen Grzegorz na biskupa bielskiego, wikariusza diecezji warszawsko-bielskiej. Podczas święta Zwiastowania (7 kwietnia) ojcowie Jakub i Grzegorz zostali podniesieni do godności archimandrytów. Arcybiskup Sawa odczytał dekret odwołujący ojca Mirona z funkcji przełożonego monasteru i proboszcza parafii. Jego obowiązki przejął przyszły biskup Jakub. Święcenia biskupie mnichów odbyły się w katedrze metropolitalnej w Warszawie kolejno 10,11 i 12 maja.

W maju 1998 r. cerkiew Zwiastowania zwieńczył ostatni krzyż. W kolejnym roku podpisano umowę z Muzeum Podlaskim na dzierżawę części pomieszczeń pod Muzeum Ikon. Na zbiory muzealne składają się ikony zatrzymane przez celników w czasie prób przemytu.

W marcu 1999 r. Sobór Biskupów powołał biskupa Jakuba na ordynariusza diecezji białostocko-gdańskiej. Pełniącym obowiązki namiestnika monasteru został archimandryta Gabriel (Giba), który funkcję tę oficjalnie przejął 1 maja $2000 \mathrm{r}$.

W 1999 r. uroczyście świętowano 500-lecie Monasteru. W maju po raz pierwszy po wielu latach rozbrzmiały stare melodie z Irmologionu Supraskiego, odnalezionego przez profesora Anatolija Konotopa, badacza historii muzyki liturgicznej. Muzyka Irmologionu jest odbiciem tradycji muzycznej starej Rusi (Radziukiewicz, 1999, s. 29). Główne obchody rocznicowe połączono ze świętem Supraskiej Ikony Matki Bożej w sierpniu. Jubileusz stał się również okazją do postawienia nowych krzyży we wsiach 
supraskiej parafii - w 1999 r. w Nowodworcach, Sokołdzie, Surażkowie, Karakulach; w 2000 r. w Supraślu (przy ul. Cieliczańskiej i na cmentarzu) i w Cieliczance.

22 listopada 1999 r. po niedzielnej Liturgii biskup Jakub dokonał poświęcenia filii białostockiego ośrodka miłosierdzia w Supraślu. Mieści się ona po dzień dzisiejszy w budynkach monasterskich. W pomieszczeniach zorganizowano biuro i świetlicę dla dzieci.

Przez cały czas nie malały starania o odzyskanie monasterskich katakumb. Działkę, na której niegdyś znajdowała się cerkiew Zmartwychwstania, otrzymała od Skarbu Państwa w 1997 r. gmina Supraśl. Mimo pozytywnych opinii gminy, co do planów Monasteru, w 1999 r. pojawił się nowy pretendent do przejęcia katakumb - parafia rzymskokatolicka. W czerwcu 2000 r. doszło do nieprzyjemnego incydentu - ksiądz rzymskokatolicki wraz z grupą młodzieży szkolnej samowolnie rozpoczęli prace porządkowe na katakumbach. „Zachowanie młodych ludzi było aroganckie, dochodziło nawet do wyśmiewania się nad ludzkimi szczątkami” (Archiwum Monasteru). Zdarzenie zauważył przejeżdżający obok katolik i od razu zainterweniował. Archimandryta Gabriel powstrzymał dewastację grobów. W międzyczasie w swoim liście z $2000 \mathrm{r}$. burmistrz Supraśla określił katakumby jako „nikomu nieprzydatne ruiny" (Radziukiewicz, 2002, s. 6). W 2003 r. na terenie katakumb, w miejscu lokalizacji dawnej cerkwi Zmartwychwstania prowadzone były prace archeologiczne. Wykopano kości, po czym poddano je wnikliwej analizie w Akademii Medycznej w Białymstoku. Szczątki zostały tymczasowo pochowane na terenie monasterskiego dziedzińca. W czerwcu 2003 r. Rada Miasta Supraśl zadecydowała o oddaniu katakumb Cerkwi.

W 2001 r. za ofiary wiernych zakupiono komplet nowych dzwonów, które odlano w Przemyślu w zakładzie Felczyńskich. Po raz pierwszy zabrzmiały na Paschę (Bołtryk, 2001, s/3-6). Uroczyście poświęcone zostały podczas święta ap. Jana Teologa w maju.

W grudniu 2003 r. na skarpie zwanej „Suchy Hrud” ustawiony został pamiątkowy krzyż. To miejsce, w którym - według tradycji - zatrzymał się krzyż puszczony nurtem rzeki Supraśl przez mnichów z pobliskiego Gródka, dając początek powstania ośrodka monastycznego w Supraślu. Krzyż poświęcił biskup Jakub w maju kolejnego roku.

W 2004 r. swoją działalność zainaugurowała Akademia Supraska - centrum konferencyjne i dom pielgrzyma. Głównym celem instytucji jest krzewienie i upowszechnianie wiedzy o bogactwie prawosławnej wiary, duchowości, tradycji i kultury. Ostatnie pomieszczenia oddane do użytku po remoncie zostały poświęcone i otwarte w 2014 r. w obecności Premiera Donalda Tuska. W 2004 r. została również wyremontowana domowa cerkiew pw. Supraskiej Ikony Matki Bożej przy ul. 3. Maja. W 2005 r. wymienione zostały kopuły na cerkwi św. Jana Teologa. Powrócono do pierwowzoru sprzed II Wojny Światowej. W tym samym roku postawiono nowy mur oddzielający teren monasteru od budynków po północnej stronie.

W 2005 r. odrodziła się pamięć o mnichu-męczenniku Antonim (XV-XVI w.), który postrzyżyny mnisze przyjął w Supraślu, a męczeńską śmierć w Salonikach (Grecja). Od tego momentu, co roku w dniu jego pamięci (4/17 lutego) odbywają się specjalne nabożeństwa.

W marcu 2008 r. Sobór Biskupów powołał archimandrytę Gabriela na biskupa gorlickiego, wikariusza diecezji przemysko-gorlickiej. Nowym przełożonym monasteru i proboszczem przymonasterskiej parafii został biskup Grzegorz, mianowany biskupem supraskim. Podczas uroczystości święta Zwiastowania ojciec Gabriel poinformował, że nie przyjmie godności. Sobór biskupów pozostawił archimandrytę w składzie braci monasterskiej.

10 kwietnia 2010 r. w tragicznej katastrofie samolotu pod Smoleńskiem wraz z Prezydentem RP Lechem Kaczyńskim i innymi ważnymi osobistościami życia publicznego w Polsce zginął także arcybiskup Miron. Jego wolą było spocząć w Supraślu, toteż po dziewięciu dniach były przełożony i budowniczy monasteru został pochowany w krypcie cerkwi Zwiastowania, tuż pod prezbiterium. Po czterech latach w południowym skrzydle kompleksu monasterskiego otwarto izbę pamięci władyki Mirona. Imię arcybiskupa nadano także ulicy przylegającej do monasteru od wschodniej strony.

Po święcie Supraskiej Ikony Bogurodzicy 10 sierpnia 2010 r. biskup Grzegorz zwołał Sobór Braci, który jednogłośnie wybrał nowego przełożonego - ihumena Andrzeja (Borkowskiego), który do wspólnoty monastycznej należał od 1993 r. 1 września został p.o. przełożonego, a w marcu 2011 r. przełożonym. W kolejnym roku podniesiono go do godności archimandryty.

W latach 2011-2016 r. trwał generalny remont cerkwi św. Jana Teologa. Wykonane zostały posadzki z ogrzewaniem podłogowym, elewacje wewnętrzne, polichromie. Wymieniono również pokrycia dachowe. Zbudowana w 1890 r. świątynia do początku XXI wieku pozostawała jeszcze nie w pełni wykończona (Radziukiewicz, 2017, s. 4). Ten etap zakończyło jej uroczyste poświęcenie w lutym 2017 r. Metropolita Sawa mówił podczas uroczystości: „Któż śmiałby myśleć w czasie wojny i po wojnie, że nastanie taki dzień jak dziś?" (Radziukiewicz, 2017, s. 4).

Prace budowlane i remontowe objęły także południowo-zachodni korpus z przeznaczeniem na część bracką - cele dla mnichów, domową cerkiew św. Antoniego Supraskiego, bibliotekę, kuchnię, refektarz. Wyremontowane skrzydło wraz z cerkwią poświęcono w dniu święta Supraskiej Ikony w sierpniu 2013 roku. Pierwszą Liturgię odprawiono tam w $2015 \mathrm{r}$.

Przez cały czas trwały prace budowlano-remontowe w cerkwi Zwiastowania - w nawie głównej, w ołtarzu, na chórze i w pomieszczeniach pomocniczych. Zimą 20172018 r. położona została marmurowa posadzka. W $2016 \mathrm{r}$. wykonano pierwszy etap fresków - w kopule i w tubusie, a w 2018 r. dwa kolejne - na łukach i sklepieniach, a także w części ołtarzowej.

Od 2014 r. w Supraślu istnieje także Muzeum Sztuki Drukarskiej i Papiernictwa, nawiązujące do dawnych drukarskich tradycji Monasteru. W tym samym roku działka, na której znajdują się katakumby, została zwrócona przez 
komisję regulacyjną do spraw Kościoła prawosławnego monasterowi. Katakumby od razu zabezpieczono.

$\mathrm{W}$ ostatnich latach wiele remontów przeprowadzono także w cmentarnej cerkwi św. Jerzego. Wzmocniono fundament, więźbę dachową i strop, stolarkę okienną, wymieniono instalację elektryczną. Dach pokryto blachą tytanową. Ściany, na których położono nowe tynku, zostały pomalowane. Na zewnątrz wyczyszczono cegły i uzupełniono ubytki. Wykonano także nowe schody.

Ważne miejsce w najnowszej historii supraskiej parafii zajmuje nowa cerkiew św. Łukasza Chirurga w Łaźniach - kaplica dla mieszkańców Łaźni, Podłaźni i innych wsi Puszczy Knyszyńskiej. Inicjatywa jej budowy zrodziła się w 2010 r., w ramach kontynuacji dawnej tradycji sprawowania Liturgii w domu pomocy w Laźniach. Działkę parafia otrzymała od gminy za symboliczną złotówkę. W 2014 r. biskup Grzegorz dokonał poświęcenia kamienia węgielnego pod budowę cerkwi, a już 11 czerwca, w dniu pamięci św. Łukasza, w budującej się świątyni odprawiono pierwszą Świętą Liturgię. Od 2018 r. Liturgia sprawowana jest w każdą drugą niedzielę miesiąca. Świątynia poświęcona została 22 czerwca $2019 \mathrm{r}$.

Cerkiew jest celem wielu pielgrzymek - pieszych, rowerowych i autokarowych. W 2018 r. na święto do Łaźni wyruszyła z Supraśla niemal setka pątników. Podczas uroczystości na niebie nad cerkwią ukazał się - nie po raz pierwszy - tęczowy krąg.

Intencją budowy cerkwi było upamiętnienie męczeńskiej śmierci mieszkańców Łaźni zamordowanych w październiku 1943 r. Biskup Andrzej we wstępie do wydanego w 2018 r. przez supraską parafię akatystu do św. Łukasza pisze: „Świątynia powstała zatem na ziemi zroszonej krwią męczenników, a patron cerkwi to wyznawca za wiarę, który także doświadczył cierpienia ze strony obydwu systemów totalitarnych - komunizmu i faszyzmu. Należy nadmienić, że ojciec św. Łukasza pochodził z Polski, zatem spełniliśmy dług wdzięczności wobec hierarchy, budując pierwszą świątynię ku jego czci w naszym kraju" (Święty Łukasz Chirurg Arcybiskup Krymski. Życie i cuda, Akatyst, 2018, s. 5). Warto dodać, że od lipca 2017 r. każdego niedzielnego wieczora $\mathrm{w}$ murach monasteru odprawiany jest akatyst do św. Łukasza ze szczególną modlitwą w intencji chorych.

24 sierpnia 2017 r. Sobór Biskupów PAKP zadecydował o zmianach w Polskiej Cerkwi. Powołano czterech nowych biskupów. Wśród nich był namiestnik Monasteru archimandryta Andrzej. Wyznaczono go na biskupa supraskiego, wikariusza diecezji białostocko-gdańskiej na miej- sce biskupa Grzegorza, który powrócił do diecezji warszawsko-bielskiej z tytułem biskupa bielskiego. Chirotonia biskupia ojca Andrzeja odbyła się 27 września w Katedrze św. Mikołaja w Białymstoku.

Od 2017 r. w Supraślu działa siestryczestwo. Aktywne panie pomagają $\mathrm{w}$ życiu parafialnym - przygotowują ciepłą herbatę i poczęstunek na spotkania z cyklu „Supraskie Środy”, śniadania po nocnych nabożeństwach, pomagają w letnich obozach, rekolekcjach dla młodzieży, dbają o parafian i pielgrzymów. Swoje święto obchodzą dwa tygodnie po święcie Paschy - w Niedzielę Niewiast niosących wonności (Żen Mironosic).

Jesienią 2017 roku rozpoczęto kurs zajęć z języka cerkiewnosłowiańskiego oraz cykl spotkań duchowo-teologicznych dla parafian i pielgrzymów pt. „Supraskie Środy". Wykłady odbywają się po środowym wieczornym akatyście i prowadzone są przez zaproszonych gości i mnichów Monasteru.

Duży nacisk w działalności parafii kładziony jest na pracę z młodzieżą. Dwa razy w roku - przed Bożym Narodzeniem i w Wielkim Poście - organizowane są w Supraślu rekolekcje (gowienija) dla chłopców z Diecezji Białostocko-Gdańskiej. Młodzież uczestniczy w nabożeństwach, zajęciach nt. spowiedzi i Eucharystii, pomaga w bieżących pracach. Latem odbywają się obozy dla młodzieży. Prowadzona jest aktywna działalność w przedszkolach i szkołach podstawowych w Supraślu i Ogrodniczkach. Duchowni Monasteru sprawują również opiekę duszpasterską nad Bractwem Trzech Świętych Hierarchów i Kołem Terenowym Bractwa świętych Cyryla i Metodego w Białymstoku.

Aktywnie działa także parafialny chór rodzinny, który poza śpiewaniem podczas nabożeństw, występuje na koncertach i festiwalach w kraju i poza granicami. Wydał już kilka płyt. Odniósł już niejeden sukces, chociażby na Międzynarodowym Festiwalu Hajnowskie Dni Muzyki Cerkiewnej.

Supraśl odwiedziło w ciągu ostatnich lat wielu zwierzchników Kościołów lokalnych m.in.: Patriarcha Konstantynopolitański Bartłomiej (1999), Patriarcha Rumunii Teoktyst (2000), Patriarcha Aleksandrii Piotr VII (2001), Arcybiskup Albanii Anastazy (2003), Arcybiskup Aten i całej Grecji Chrystodulos (2005), Patriarcha Gruzji Eliasz II (2005), Arcybiskup Synaju Damian (2007), Arcybiskup Cypru Chryzostom II (2008), Patriarcha Jerozolimski Teofil III (2010), Patriarcha Moskiewski i całej Rusi Cyryl (2012), Patriarcha Antiochii i całego Wschodu Jan X (2016), Metropolita Ameryki i Kanady Tichon (2018).

\section{Bibliografia}

Bołtryk M., (2001). A na Paschę zadzwonity, w: Przeglad Prawosławny, nr 5 (191) 2001, Białystok.

Borowik S. (2000), Supraskie cmentarze, w: Przeglad Prawostawny, nr 4 (178), kwiecień 2000, Białystok, 2000.

Dalmatov N. (1892), Suprasl'skij Blagoveŝenskij Monastyr'. Istoriko-statističeskoe opisanie, Sankt-Petersburg [Далматов Н.
(1892), Супрасльский Благовещенский Монастырь. Историко-статистическое описание, Sankt-Petersburg].

Kuprianowicz G. (2009), Prawostawie w Polsce od 1918 roku do współczesności, w: Prawosławie. Światło ze wschodu, red. K. Leśniewski, Lublin.

Makal W. (2003), Przed odrodzeniem Supraskiego Monasteru. 
Historia Parafii Prawosławnej w Supraślu w latach 19311984, Supraśl.

Mironowicz A. (2006), Kościół prawosławny w Polsce, Białystok.

Mironowicz A. (2013), O początkach monasteru supraskiego i jego fundatorach, Supraśl.

Radziukiewicz A. (2002), Kości niezgody, w: Przegląd Prawostawny, nr 8 (206) 2002, Białystok.

Radziukiewicz A. (1999), Triumfalny powrót Supraskiego Irmołogionu, w: Przeglad Prawosławny, nr 5 (166), maj 1999, Białystok.

Radziukiewicz A. (2015), Monaster w Supraślu, Supraśl.

Radziukiewicz A. (2017), Wyświęcono cerkiew św. Jana Teologa, w: Przegląd Prawostawny, nr 3 (381) 2017, Białystok.

Hrycuniak Sawa, metropolita (2005), Supraski Monaster Zwiastowania Przenajświętszej Bogarodzicy i jego historyczna rola $w$ rozwoju społeczności lokalnej $i$ dziejach Prawostawia: tytułem wprowadzenia, w: Z dziejów Monasteru Supra- skiego: materiaty międzynarodowej konferencji naukowej "Supraski monaster Zwiastowania Przenajświętszej Bogarodzicy i jego historyczna rola w rozwoju społeczności lokalnej i dziejach państwa”, Supraśl.

Shved V. (2015), Działalność supraskiego Bractwa Zwiastowania NMP (1893-1896), w: Dzieje opactwa supraskiego, Rzym-Lublin-Mińsk.

Surynowicz H. (2001), Życie monastyczne na Grodzieńszczyźnie w XIX w., w: Życie monastyczne w Rzeczypospolitej, Białystok.

Kościót Prawosławny w Polsce dawniej i dziś. Aneks statystyczny z parafialnych ksiag metrykalnych białostocczyzny XVIII, XIX i XX wieku, 1993, Główny Urząd Statystyczny, Warszawska Metropolia Prawosławna, Warszawa.

Materiały Archiwum Monasteru.

Nowa Europa, 20.07.1992.

Święty Lukasz Chirurg Arcybiskup Krymski. Życie i cuda, Akatyst, 2018, Supraśl.

Rozmiar artykułu: 1,3 arkusza wydawniczego 
ISSN 1508-7719

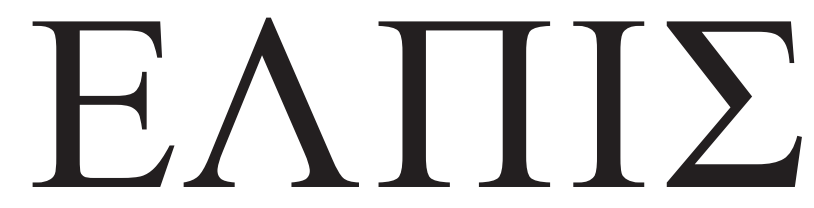

CZASOPISMO TEOLOGICZNE KATEDRY TEOLOGII PRAWOSŁAWNEJ UNIWERSYTETU W BIAŁYMSTOKU

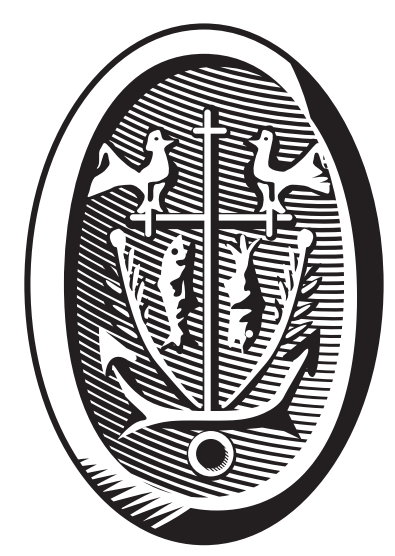

ADRES REDAKCJI

ul. Ludwika Zamenhofa 15, 15-435 Białystok, Polska tel. 85 745-77-80, e-mail: elpis@uwb.edu.pl www.elpis.uwb.edu.pl 